\title{
Hydrobiological study of a reservoir in the central Apennines (Italy)
}

\author{
K. Bartolelli1 ${ }^{1}$, M. Cocchioni², A. Dell'Uomo ${ }^{1 *}$, S. Scuri² \\ 1 Dipartimento di Botanica ed Ecologia, Università di Camerino, Via Pontoni 5, I-62032 Camerino (MC), Italy. \\ 2 Dipartimento di Scienze Igienistiche e Sanitarie-Ambientali, Università di Camerino, Via E. Betti 3, I-62032 Camerino (MC), Italy.
}

\begin{abstract}
Chemical, chemical-physical and biological procedures were employed to carry out a hydrobiological study of a reservoir in the central Apennines (Italy), designed for the supply of drinking and irrigation water, and tourist recreation facilities. Potentiometric, volumetric, spectrophotometric, and chromatographic techniques were used for the chemical-physical analyses, while the OECD method was adopted to assess the trophic level. The phosphorus and chlorophyll values evidenced the oligomesotrophic condition of the reservoir, with a dominance of the oligotrophic level. The analysis of the net-phytoplankton community showed the prevalence of the oligotrophic level, with a smaller tendency to the mesotrophic one. The dominant species were Dinobryon divergens Imhof and D. sertularia Ehrenb. among the Chrysophyceae, and Ceratium hirundinella (O.F. Müll.) Dujardin and Peridinium cinctum Ehrenb. among the Dinophyceae. However, some potentially dangerous inocula (Planktothrix agardhii (Gom.) Anagnostidis et Komárek and Microcystis aeruginosa (Kütz.) Kützing were present, suggesting that the reservoir should be kept under accurate observation.
\end{abstract}

Keywords : chemical-physical analyses, net-phytoplankton, trophic level, reservoir, central Italy.

\section{Introduction}

In natural lakes and in reservoirs created by man for tourism, fishing, production of hydroelectric power, irrigation, and for satisfying the growing need for drinking water, algae bloom form an increasing problem throughout the world, in particular when they are accompanied by the production of biotoxins. Generally caused by an excess of nutrients in the reservoirs, blooms have recently occurred with a seasonal periodicity in many lakes in central and southern Italy. They also appeared in the Marches region (central Italy) with a reddening, during winter, of the waters of the artificial lake of Fiastra in the province of Macerata, caused by Planktothrix agardhii (Gom.) Anagnostidis et Komárek. Other blooms, reported with particular frequency in lakes in Europe and worldwide, are also due to Cyanobacteria. Among the most common, there are

\footnotetext{
* Corresponding author :

E-mail: antonio.delluomo@unicam.it
}

Microcystis aeruginosa (Kütz.) Kützing, Microcystis flos-aquae (Wittr.) Kirchn., Anabaena flos-aquae (Lyngb.) Bréb. ex Born. et Flah., Aphanizomenon flosaquae (L.) Ralfs ex Born. et Flah. and Planktothrix rubescens (DC. ex Gom.) Anagnostidis et Komárek. The production of biotoxins (microcystines, saxitoxins, anatoxins, etc.) that have often accompanied the appearance and blooms of these organisms put at risk the use of the waters, causing serious damage to the economy and threatening public health. This problem has been emphasized at several international meetings during the last decade (e.g. Reguera et al. 1998, Chorus \& Bartram 1999). With the aim of preventing and possibly identifying the causes of dangerous blooms in a lake serving for water supply, and in order to assess its current trophic situation, a chemical and biological monitoring was set up.

\section{Materials and methods}

The studied reservoir "Lago di Castreccioni" (Fig. 1 ), was made by damming the upper valley of the Ri- 


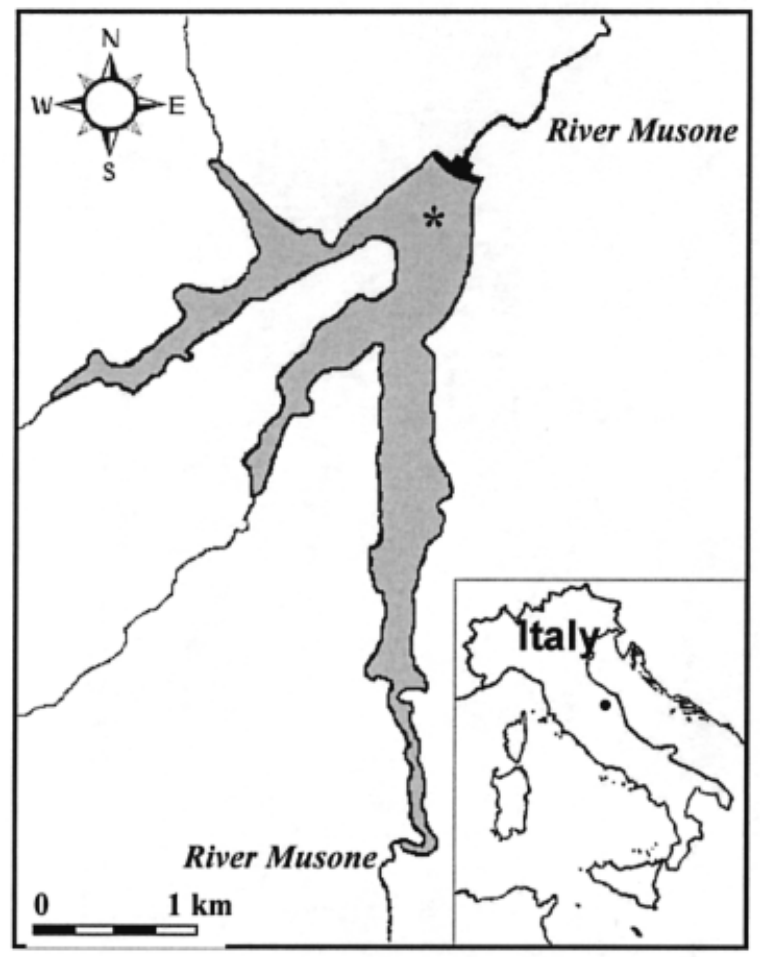

Fig. 1. Map of the reservoir with the sampling station (*), and its location in central Italy.

ver Musone (central Apennines, Marches region). The dam construction started in 1983, but water catchment began only in 1987. Located at ca $300 \mathrm{~m}$ a.s.l., the basin has a capacity of $50 \cdot 10^{6} \mathrm{~m}^{3}$ and covers an area of 150 ha. The maximum depth is ca $50 \mathrm{~m}$, the average depth is $24 \mathrm{~m}$, and the catchment basin is $90 \mathrm{~km}^{2}$. At present, for technical reasons, the volume of the basin is fixed at about $20 \cdot 10^{6} \mathrm{~m}^{3}$ and the theoretical turnover time of the waters is situated at ca 8 months. The dam (67 $\mathrm{m}$ high and $280 \mathrm{~m}$ long) is situated on a homogeneous calcareous-majolica formation (Upper JurassicLower Cretaceous) belonging to the prevalently limestone unit of the Umbro-Marchean sequence. A complex plant making use of the latest technology and having a potential of $500 \mathrm{l} \cdot \mathrm{s}^{-1}$ makes the lake waters drinkable (Cocchioni et al.1999).

The River Musone, which is the most important affluent of the lake, supplies ca $60 \%$ of the water; it runs almost transversally from west to east through the Marches region and comes out into the Adriatic Sea to the south of Mt. Conero (572 m) and the city of Ancona. The area drained is hilly-mountainous. The prima- ry activity is traditional agriculture with intensive animal breeding. The built-up areas are of modest size but the settlements spread over the territory have acquired vitality with the coming of tourism to the lake.

After a preliminary survey to define the most significant points for typifying the ecosystem, and after evidencing a substantial uniformity in the characteristics of the water at the points tested, sampling was carried out using a small boat in the centre of the lake at a distance of ca $150 \mathrm{~m}$ from the dam and the shores. From July 2001 to June 2002 the investigation was made using a Van Dorn-type sampler, with monthly samplings of the chemical, chemical-physical and bacteriological parameters at the surface and at depths of 1 , $6,9,15$ and $25 \mathrm{~m}$. For temperature and dissolved oxygen, which are fundamental parameters for studying thermal stratification phenomena, measurements were made at $1 \mathrm{~m}$ intervals throughout the water column. The chemical, chemical-physical, and bacteriological analyses were carried out using potentiometric, volumetric, spectrophotometric (molecular adsorption, nuclear adsorption) and chromatographic (gas chromatographic, ion chromatographic) techniques according to the methods described by the Institute for Water Research in Rome (Irsa-Cnr 1994) and by APHA, AWWA \& WEF (1998).

To assess the trophic level, both chemical-physical and biological procedures were adopted. For the former, the method introduced by the Organization for Economic Cooperation and Development was used; this foresees both fixed boundary system and probability distribution for trophic categories (Vollenweider \& Kerekes 1982). With regard to the fixed boundary system, the trophic levels were assessed on the basis of the absolute values of the various parameters; instead, for calculating the probability distribution, the criterion was introduced according to which an environment can be ascribed to one or several trophic levels on the basis of the phosphorus, transparency, and chlorophyll values, with a precise degree of probability.

To deal with the biological aspect, the phytoplankton community was studied. Six samplings were carried out on the following dates : June 2001, July 2001, September 2001, November 2001, March 2002 and June 2002. Samples were taken in the centre of the lake using a $25 \mu \mathrm{m}$ mesh plankton net. Horizontal and vertical sweeps were made in the photic zone. To determine the species, a Leitz-Dialux 22 microscope automatically equipped for microphotography was used. Preliminary observations were made on fresh material, and then the samples were fixed with addition of $5 \%$ neutralized formalin. Essentially, the following au- 


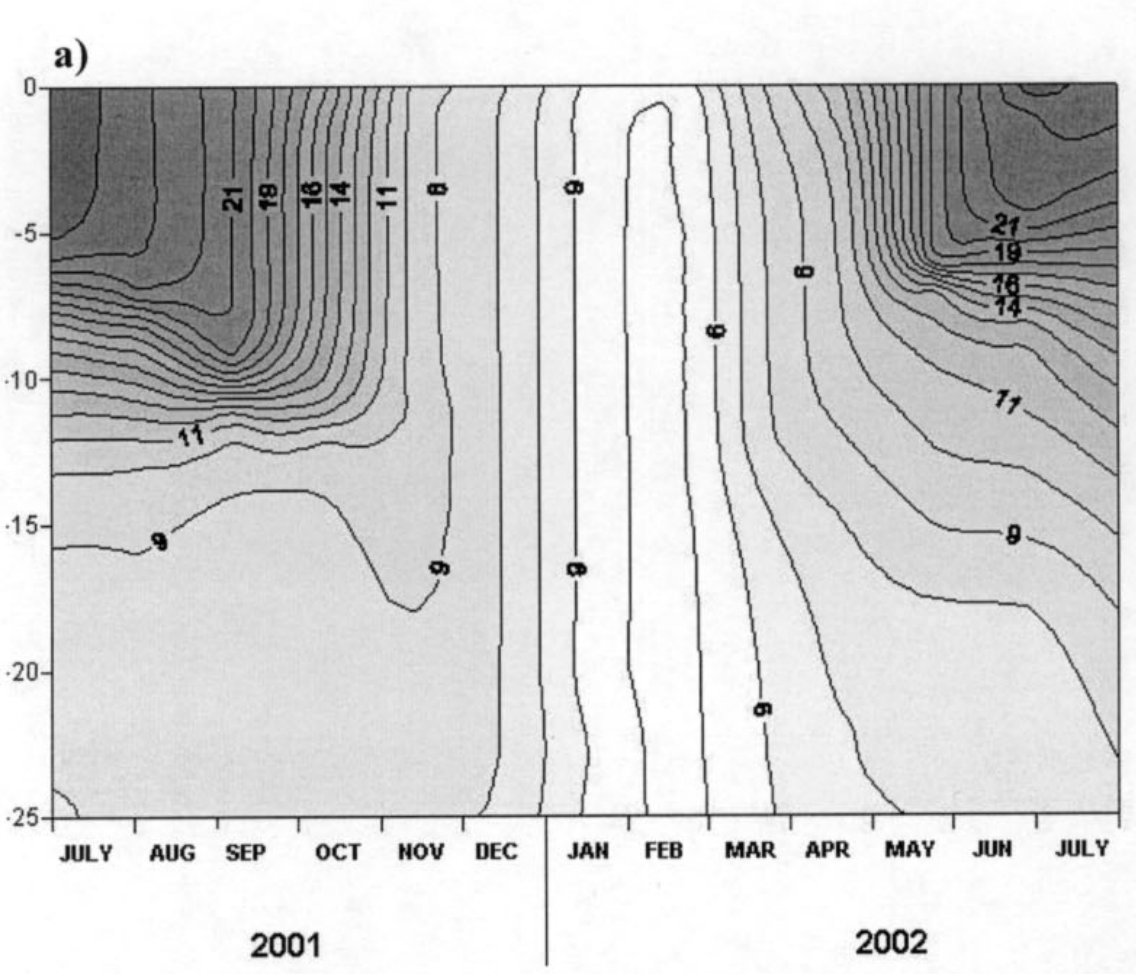

${ }^{\circ} \mathrm{C}$

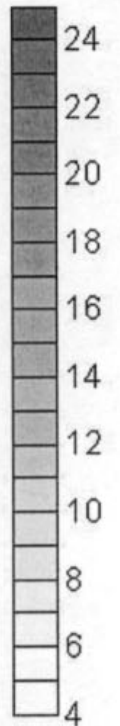

b)
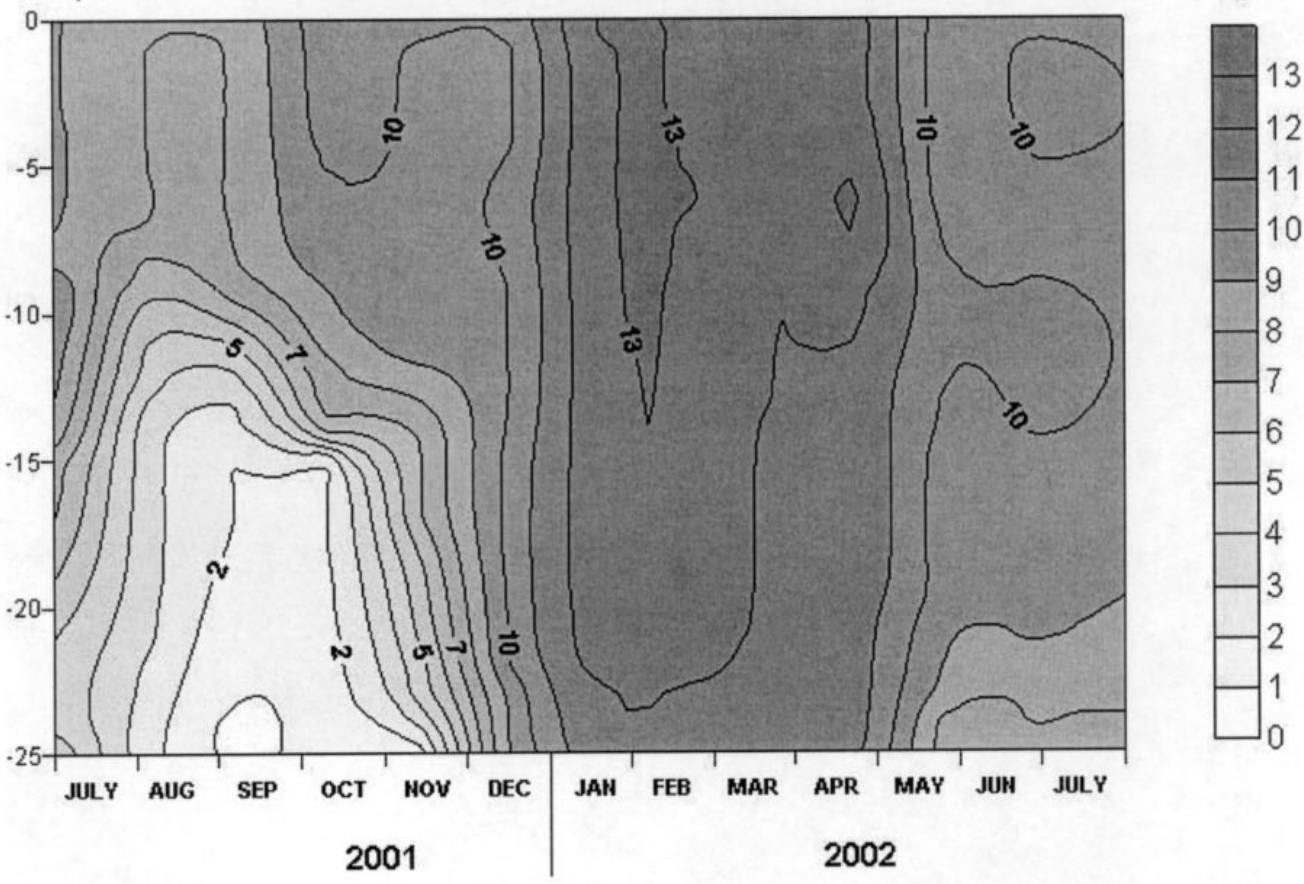

Fig. 2. a) Depth-time diagram of isotherms. b) Depth-time diagram of isopleths of dissolved oxygen. 
thors were consulted for identification and naming of the species: Geitler (1932), Desikachary (1959), Compère (1986), Anagnostidis \& Komárek (1988), Komárek \& Anagnostidis (1999) for the Cyanobacteria; Popovsky \& Pfiester (1990) for the Dinophyceae; Prescott (1970), Compère (1989) for the Cryptophyceae; Starmach (1985) for the Chrysophyceae; Krammer \& Lange-Bertalot (1991) for the Bacillariophyceae; Philipose (1967), Prescott (1970), Ettl (1983), Ettl \& Gärtner (1988) for the Chlorophyceae; Ruzicka (1977) for the Zygophyceae.

The interpretation of the ecological significance of the phytoplankton community of the reservoir was made, among others, by means of Sladecek (1973), Round (1981), Reynolds (1984), Dell'Uomo \& Masi (1988), Cronberg \& Komárek (1994), Komárek \& Anagnostidis (1999).

\section{Chemical, chemical-physical and bacterio- logical features}

\section{Temperature, thermal stratification and oxygen} (Fig. 2a, Fig. 2b)

In lacustrine environments, the temperature of the water mass plays a determinant role that is not limited only to the physical aspects, but that substantially involves the water chemistry and, in particular, the oxygen balance. In July and August, a thermal stratification was observed: the temperature remained almost constant in the epilimnion at around $25^{\circ} \mathrm{C}$, then underwent a rapid change from 6 to $10 \mathrm{~m}$ depth (metalimnion), and tended to set at $10^{\circ} \mathrm{C}$ below $12 \mathrm{~m}$. The lowest levels (hypolimnion) remained cut off from the atmosphere, and the oxygen accumulating during the remixing phase was progressively consumed by the biochemical oxidation processes of the organic matter and high values of hypoxia were reached. Concomitantly, consistent amounts of ammonia appeared in connection with the interruption of the mineralising processes (Chapman 1992). In the same period at the surface (epilimnion), oxygen concentrations oscillated around $100 \%$ saturation due to solubilization of the atmospheric oxygen and to photosynthetic activity. Reoxygenation of the hypolimnion level was attained only in December and January since the epilimnion had cooled down and the temperature became uniform throughout the water column; thus the force of the winds was easily able to remix the water mass and oxygenated even the lowest levels.

\section{Ion composition (Table 1)}

Table 1 reports the mean ion composition found in the central part of the lake at $0.2 \mathrm{~m}$ depth. A rapid analysis of the ionic species reveals the clear predominance of calcium for the cations, and of bicarbonates for the anions. The water can thus be classified as bicarbonate-calcic.

\section{Electric conductivity (Table 1)}

The conductivity values oscillated in the range of $389-499 \mu \mathrm{S} \cdot \mathrm{cm}^{-1}$. The trend recorded in the individual months at the various depths indicates a substantial constancy throughout the water column in the coldest months, consistent with the remixing phase, whereas in the periods of thermal stratification the conductivity values remained almost constant in the epilimnion level, but the increase significantly went down towards the hypolimnion. This trend can be attributed in part to phenomena of sedimentation, decomposition, and mineralization of the organic substances at the bottom.

\section{pH (Table 1)}

When studying the ecosystem of a lacustrine environment, the $\mathrm{pH}$ supplies valuable information about the trophic level since this is directly correlated with the photosynthetic activity. In fact, it tends to shift towards basicity due to the assimilation of $\mathrm{CO}_{2}$ on the part of the vegetal organisms during the photosynthetic processes. Therefore, the higher the trophic level, the more evident will be the $\mathrm{pH}$ oscillation values. In the Castreccioni basin, limited oscillations of the $\mathrm{pH}$ values were recorded (7.3-8.4), due also to the modest trophic level of the waters. The highest values were recorded in the euphotic zone of the epilimnion where the phytoplankton photosynthetic activity was prevalently located.

\section{Total hardness (Table 1)}

The total hardness oscillated in the range of $20.04{ }^{\circ} \mathrm{F}$ to $29.90^{\circ} \mathrm{F}$. Generally, the values were lowest at the surface while they tended to increase towards the bottom. This trend reflects the one already mentioned for electric conductivity: a greater constancy of values in the periods of circulation and a more significant increase in the warmest months in presence of stratification. The importance of more or less high calcium concentrations should be pointed out for the trophic level since calcium can bind the phosphorus and reduce the trophic effect.

\section{The organic load : BOD-COD (Table 1)}

The organic load proved relatively modest with 
Table 1. Physical, chemical and bacteriological features of the reservoir.

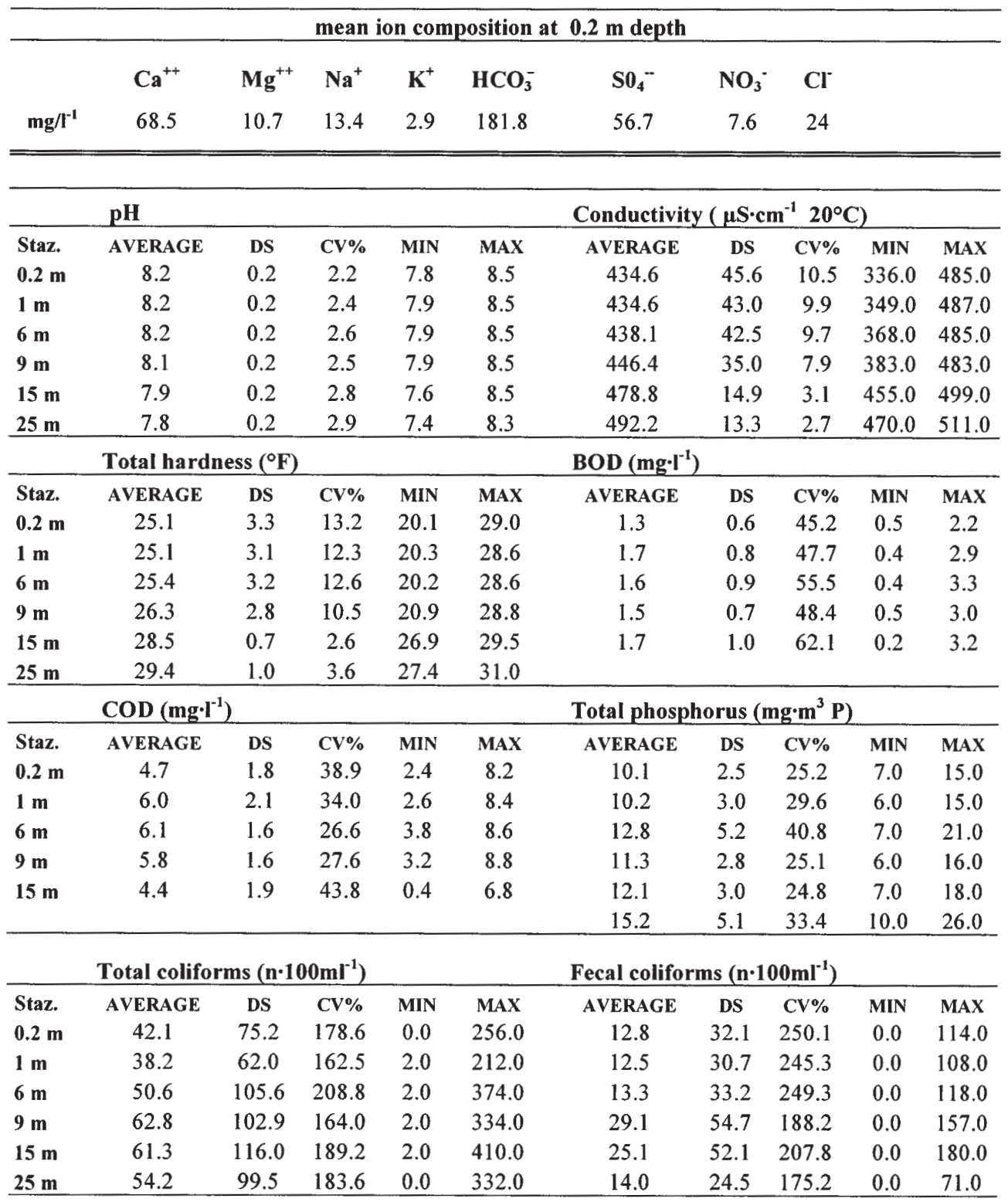

$\mathrm{BOD}_{5}$ oscillating on average around $1 \mathrm{~m} \mathrm{~g} \cdot \mathrm{l}^{-1}$ without macroscopic variations in the water column. COD was present at a higher oscillation range with the highest values being recorded in March 2002.

\section{Total coliforms, fecal coliforms (Table 1)}

These germs are a faithful indicator of the presence of sewage discharge and indirectly measure the risk of infection represented by pathogenic germs that may be present in the intestine and eliminated in fecal form. The mean values denoted a limited amount of feculence of the reservoir. On analysis, the colimetric trend was found to be univocal throughout the water column, even though a tendency to increase at intermediate depths could be noted. 


\section{Ammonia - $\mathrm{NH}_{4}{ }^{+}$(Fig. 3)}

The values recorded in the sampling campaign oscillated between 0.06 and $0.19 \mathrm{mg} \cdot \mathrm{l}^{-1}$ with a mean value of $0.15 \mathrm{mg} \cdot \mathrm{l}^{-1}$. An analysis of the trend recorded in the various months in the water column revealed that the highest values were found near the bottom, and in par- ticular in those periods when, due to thermal stratification, the hypoxia phenomena were more evident. In the epilimnion, the greatest concentrations were recorded in the months of July and August, which can be correlated with the greater anthropic presence due to tourism at the lake.
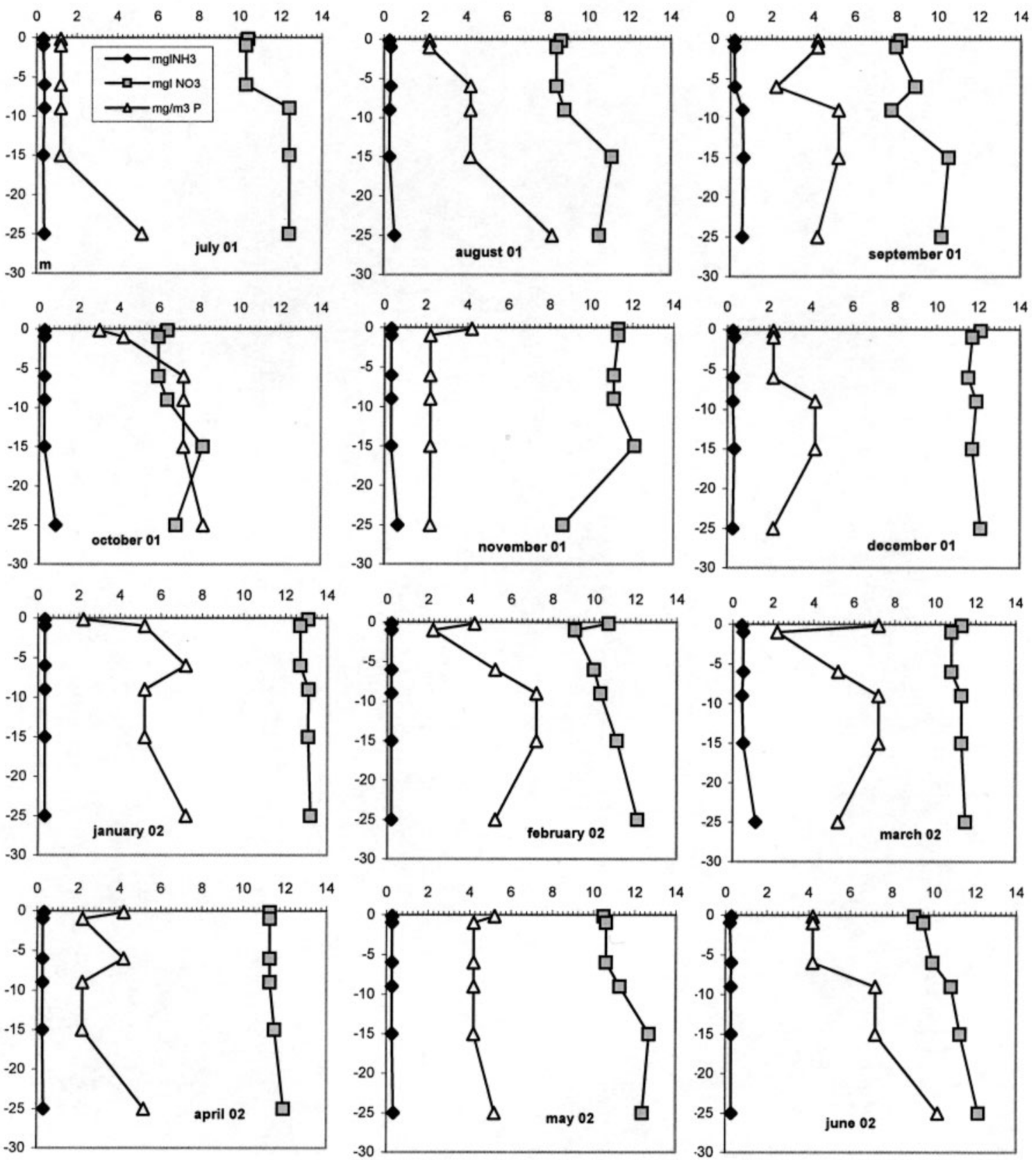

Fig. 3. Depth-diagram of monthly concentrations of ammonia, nitrates and orthophosphates. 


\section{Nitrates - $\mathrm{NO}_{3}^{-}$(Fig. 3)}

Together with phosphates, nitrates contribute to fertilize the waters and enhance the development of algae. In the Castreccioni reservoir, a slight concentration of nitrates was recorded with values oscillating in the range of 4.2 to $12.5 \mathrm{mg} \cdot \mathrm{l}^{-1}$ with a mean annual value around $9 \mathrm{mg}^{-1} \mathrm{l}^{-1}$. Substantial constancy was recorded at the various depths.

Total phosphorus - P and orthophosphates $\mathrm{PO}_{4}{ }^{3-} \mathrm{P}$ (Fig. 3)

The total values for phosphorus and orthophosphates were well contained, oscillating from a minimum of 3 $\mathrm{mg} \cdot \mathrm{m}^{-3}$ to a maximum of $30 \mathrm{mg} \cdot \mathrm{m}^{-3}$. Phosphorus is one of the main parameters considered when defining the trophic level of a lake, together with transparency and chlorophyll.

Microelements : lead, cadmium, chromium, copper, manganese, zinc

Concentrations of the order of $1 \mu \mathrm{g} \cdot \mathrm{l}^{-1}$, or fractions of that, were revealed for $\mathrm{Pb}, \mathrm{Cd}, \mathrm{Cr}$ and $\mathrm{Cu}$, whereas higher values were found for manganese and zinc. For manganese, anomalous concentrations (up to $500 \mu \mathrm{g} . \mathrm{l}^{-}$ 1 ) were found in the October and November samples taken at a depth of $25 \mathrm{~m}$. This phenomenon may be connected with solubilization of the element from the sediments in association with marked hypolimnion hypoxia phenomena.

\section{Biological aspects}

In the phytoplankton community 43 taxa were observed (Table 2), distributed as follows: Cyanobacteria 10, Dinophyceae 3, Chryptophyceae 2, Chrysophyceae 5, Bacillariophyceae 7, Chlorophyceae 14, and Zygophyceae 2. Fig. 4 shows the seasonal variations in the qualitative composition of the phytoplankton community. Some of the most representative species of the reservoir are reported in Fig. 5.

The qualitatively and quantitatively richest samplings were those from June to October, with the dinoflagellates Ceratium hirundinella (O.F. Müll.) Dujardin (Fig. 5b) and Peridinium cinctum Ehrenb., the Chrysophyceae Dinobryon divergens Imhof and Dinobryon sertularia Ehrenb.(Fig. 5d), and the diatoms Asterionella formosa Hassall and Cyclotella ocellata Pantocsek. The taxa observed during the period under observation were the diatoms Cyclotella ocellata and Fragilaria ulna (Nitz.) Lange-Bert., the Chlorophyceae Botryococcus braunii Kützing and Eudorina elegans Ehrenb. and again the dinoflagellates Ceratium hirundinella and Peridinium cinctum.

Usually characteristic of environments with a high trophic level, the Cyanobacteria were present in the reservoir with only a small number of individuals for each taxon. However, particular mention should be made of Planktothrix agardhii (Fig. 5a) and Microcystis aeruginosa (Fig. 5c), two species that most frequently form

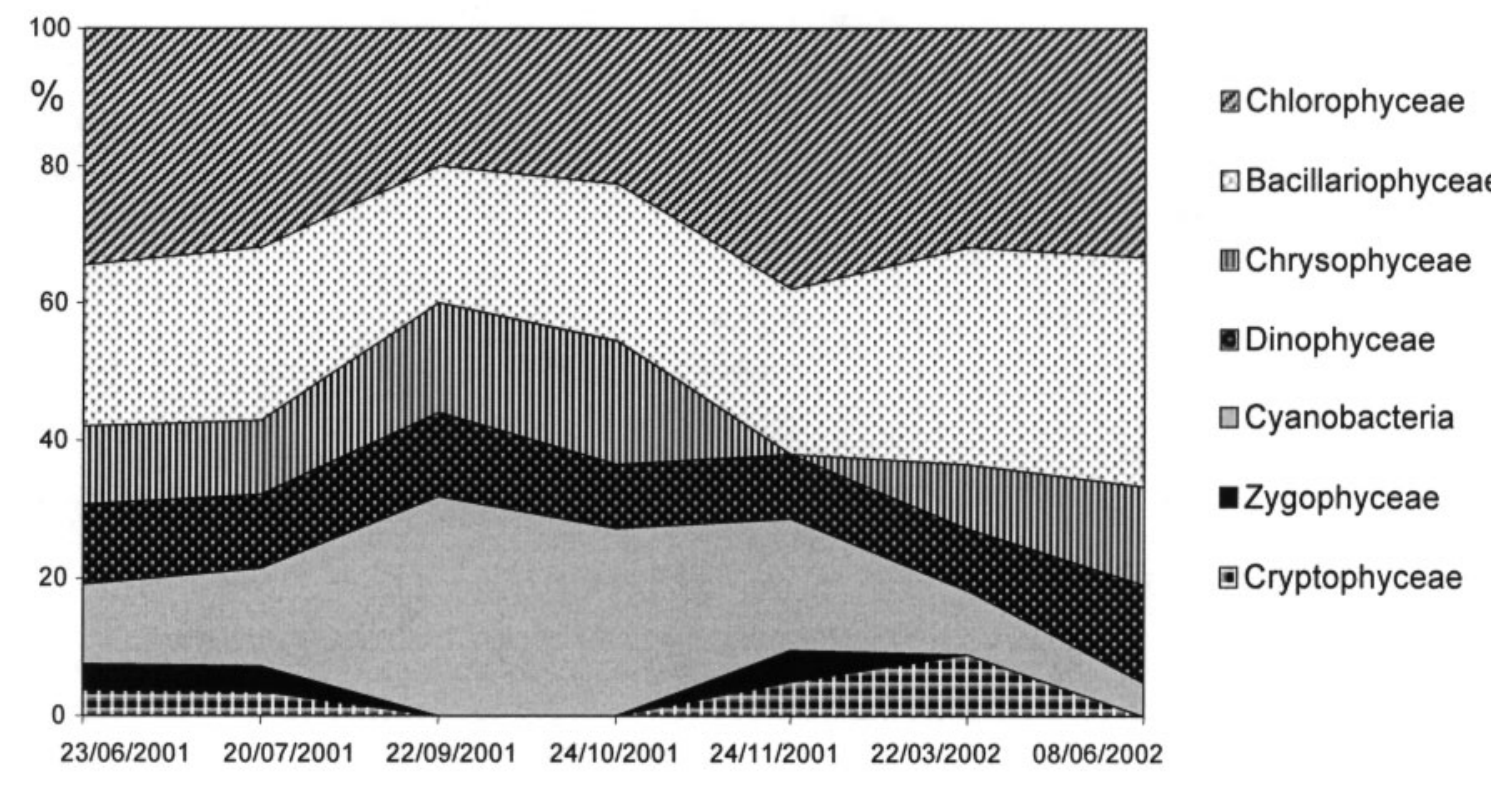

Fig. 4. Seasonal qualitative changes in the phytoplankton community during the period June 2001 - June 2002. 
waterblooms in favourable environmental conditions. These blooms, often coupled with the production of microcystins, strongly compromise the use of the reservoirs for wildlife, drinking purposes or recreation (Falconer 2001).

The microcystins are the most common type of hepatotoxins. Intracellular cyanotoxins are released into the water upon cell death or senescence due to water treatment with algicides or oxidant agents (Falconer 1993, Jones \& Orr 1994). The treatments for rendering the contaminated waters drinkable can be very expensive, though efficient and safe, such as the one using

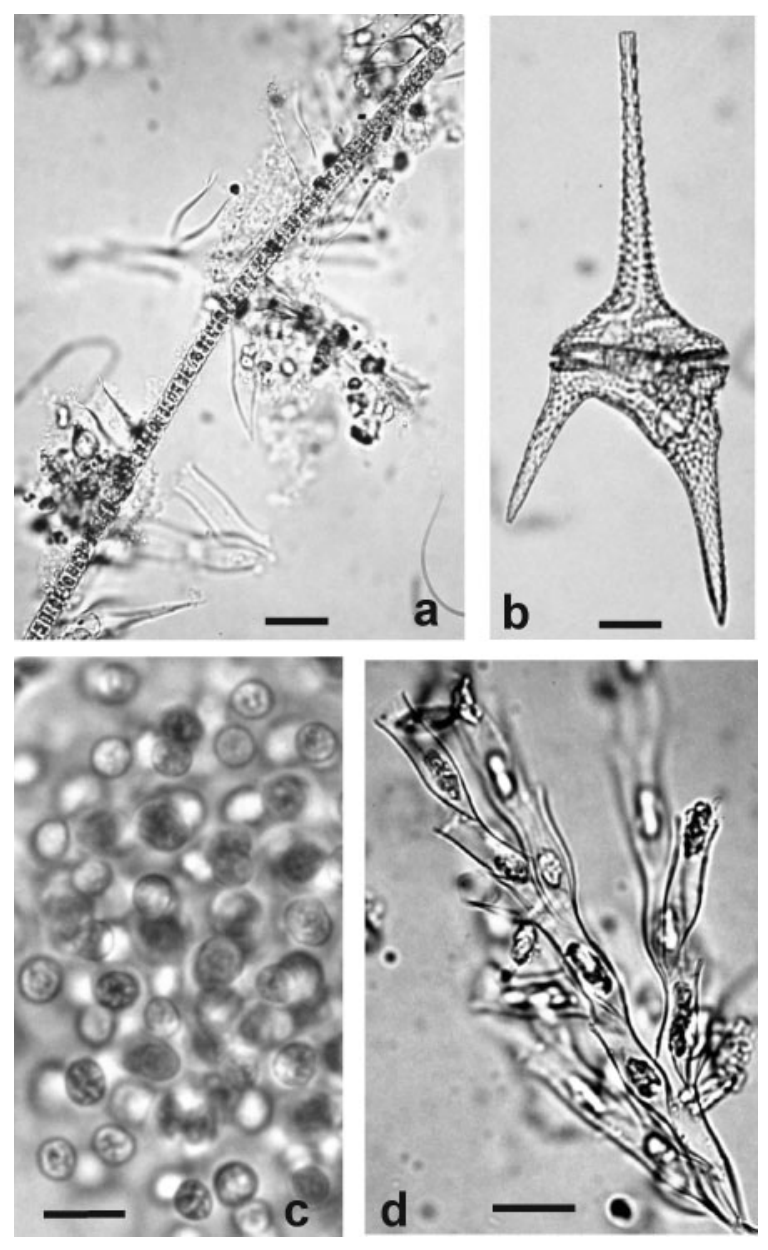

Fig. 5. Some of the most interesting and/or abundant species found in the phytoplankton of the reservoir : a - Planktothrix agardhii (Gom.) Anagnostidis et Komárek ; b - Ceratium hirundinella (O.F. Müll.) Dujardin ; c - Microcystis aeruginosa (Kütz.) Kützing ; d - Dinobryon sertularia Ehrenb. [Scale bar for Figs a, b, d $=20 \mu \mathrm{m}$; scale bar for Fig. $\mathrm{c}=10 \mu \mathrm{m}$ ]. granular active carbon filters or GAC (Falconer 1989, Himberg et al. 1989). Thus arises the need to continually monitor the lakes and reservoirs destined for such uses, in order to prevent the formation of potentially toxic blooms.

The following are the most commonly reported conditions to explain the massive development of cyanobacterial blooms in lakes and artificial reservoirs: elevated water temperature; thermal stratification; well illuminated surface water; adaptation to low intensities of light thanks to a rich supply of pigments; elevated degree of trophism of the water; low N/P ratio, benefiting nitrogen-fixing species; the possibility of migrating vertically in the water column, due above all to the presence of gas-vacuoles, for optimum exploitation of the light and nutrient gradients; ability to use $\mathrm{CO}_{2}$ efficiently, even at low concentrations; the possession of metabolic systems for accumulating phosphorus, to be exploited in periods when this element is scarce; reduced grazing by the zooplankton compared to other phytoplankton algae.

However, not all observations are quite in accordance with those above reported. Sanchis et al. (2002) hold that neither temperature nor N/P ratio are related to bloom development of Microcystis wesenbergii (Komárek) Komárek in the Santillana Reservoir (Spain), a eutrophic stratified water body; instead, they attribute the phenomenon to the high nutrient concentration, in particular ammonium, and the stability of the water column. Sabour et al. (2002) observed that the spectacular bloom of Microcystis ichthyoblable Kützing in the Oued Mellah reservoir (Morocco) was characterized by high temperatures and strong luminous intensity, while contents in major nutrients, especially nitrates and orthophosphates, were very limiting. Compared to the ecological needs held to be of general validity for Cyanobacteria, there are some differences between Microcystis aeruginosa and Planktothrix agardhii, the latter being understood as the Planktothrix (Oscillatoria) agardhii-rubescens complex :

- Planktothrix prefers low temperatures and behaves like a cold water stenotherm (Reynolds 1984), while Microcystis aeruginosa, the most common species of the genus, requires higher temperatures.

- The inverse happens in terms of light, because $M i$ crocystis needs elevated luminous intensity and thus requires water column stability; Planktothrix, instead, tolerates low luminous radiation because it possesses carotenoids in abundance in its thylakoids, and thus it does better in stirred up, turbid or poorly illuminated waters (Reynolds 1994). 
Table 2. List of the net-phytoplankton species found in the period June 2001 - June 2002 and their relative abundance. I-II-III-IV-V-VI-VII = samplings carried out on the following dates: 23/06/2001, 20/07/2001, 22/09/2001, 24/10/2001, 24/11/2001, 22/03/2002, 08/06/2002, respectively. $+++=$ dominant to abundant $(>50 \%) ;++=$ common $(5-50 \%) ;+=$ rare $(<5 \%) ;-=$ absent.

\begin{tabular}{|c|c|c|c|c|c|c|c|}
\hline Taxa & I & II & III & IV & $\mathrm{V}$ & VI & VII \\
\hline Cyanobacteria & & & & & & & \\
\hline $\begin{array}{l}\text { Aphanocapsa delicatissima W. et G.S. West } \\
\text { Aphanocapsa incerta (Lemm.) Cronberg et }\end{array}$ & - & + & + & + & - & - & - \\
\hline $\begin{array}{l}\text { Komárek } \\
\text { Aphanocapsa planctonica (G.M.Smith) }\end{array}$ & - & - & + & - & - & - & - \\
\hline Anagnostidis et Komárek & - & + & + & - & - & - & - \\
\hline Chroococcus limneticus Lemmermann & + & + & + & + & + & - & + \\
\hline Merismopedia glauca (Ehrenberg) Kützing & + & + & + & - & - & - & - \\
\hline Microcystis aeruginosa (Kützing) Kützing & - & - & + & + & + & - & - \\
\hline Oscillatoria limosa Agardh & - & - & + & + & + & - & - \\
\hline $\begin{array}{l}\text { Planktothrix agardhii (Gomont) Anagnostidis et } \\
\text { Komárek }\end{array}$ & - & - & + & + & + & + & - \\
\hline Rhabdogloea smithii (R. et F. Chodat) Komárek & + & - & - & - & - & + & - \\
\hline $\begin{array}{l}\text { Spirulina gigantea } \text { Schmidle } \\
\text { Dinophyceae }\end{array}$ & - & - & - & + & - & - & - \\
\hline $\begin{array}{l}\text { Ceratium hirundinella (O. F. Müller) Dujardin } \\
\text { Ceratium hirundinella fo. piburgense (Zederbauer) }\end{array}$ & +++ & ++ & +++ & ++ & + & + & +++ \\
\hline Bachmann & ++ & + & + & - & - & - & + \\
\hline $\begin{array}{l}\text { Peridinium cinctum } \text { Ehrenberg } \\
\text { Cryptophyceae }\end{array}$ & + & + & +++ & +++ & + & + & + \\
\hline Chroomonas nordstedtii Hansgirg & - & - & - & - & - & + & - \\
\hline $\begin{array}{l}\text { Cryptomonas erosa Ehrenberg } \\
\text { Chrysophyceae }\end{array}$ & + & + & - & - & + & + & - \\
\hline Dinobryon bavaricum Imhof & - & - & + & + & - & - & - \\
\hline Dinobryon divergens Imhof & +++ & + & - & ++ & - & + & ++ \\
\hline Dinobryon sertularia Ehrenberg & + & +++ & +++ & ++ & - & + & + \\
\hline $\begin{array}{l}\text { Dinobryon sertularia var, protuberans } \\
\text { (Lemmermann) Krieger }\end{array}$ & - & + & + & + & - & - & + \\
\hline $\begin{array}{l}\text { Dinobryon sociale Ehrenberg var. stipitatum } \\
\text { (Stein) Lemmermann }\end{array}$ & + & - & ++ & - & - & - & - \\
\hline Bacillariophyceae & & & & & & & \\
\hline Asterionella formosa Hassall & +++ & + & - & + & + & + & + \\
\hline Cyclotella ocellata Pantocsek & + & ++ & ++ & ++ & ++ & ++ & ++ \\
\hline Cyclotella schumannii (Grunow) Håkansson & + & + & + & + & - & + & + \\
\hline Diatoma tenuis Agardh & - & + & + & - & + & + & + \\
\hline Fragilaria capucina Desmazières & + & + & - & + & + & ++ & + \\
\hline Fragilaria ulna (Nitzsch) Lange-Bertalot & + & + & + & + & + & ++ & + \\
\hline $\begin{array}{l}\text { Fragilaria ulna var. acus (Kützing) Lange-Bertalot } \\
\text { Chlorophyceae }\end{array}$ & + & + & + & - & - & + & + \\
\hline Ankistrodesmus falcatus (Corda) Ralfs & + & - & - & - & - & + & - \\
\hline Asterococcus limneticus G. M. Smith & - & + & - & - & - & + & - \\
\hline Botryococcus braunii Kützing & ++ & ++ & + & + & + & + & ++ \\
\hline Chlamydomonas debaryana Goroschankin & - & + & + & - & - & - & + \\
\hline Crucigenia quadrata Morren & - & - & - & - & + & - & - \\
\hline Coelastrum microporum Nägeli & + & - & - & + & + & + & - \\
\hline Coelastrum reticulatum (Dangeard) Senn & + & ++ & + & + & + & - & - \\
\hline Eudorina elegans Ehrenberg & ++ & + & + & + & + & + & + \\
\hline Eudorina unicocca G. M. Smith & + & + & - & + & - & + & + \\
\hline Oocystis gloeocystiformis Borge & + & + & - & - & + & + & + \\
\hline Pandorina morum (O. F. Muller) Bory & + & - & - & - & - & - & + \\
\hline Pediastrum boryanum (Turpin) Meneghini & - & + & - & - & + & - & - \\
\hline Pediastrium integrum Nägeli & - & + & - & - & - & - & + \\
\hline $\begin{array}{r}\text { Sphaerocystis schroeterii Chodat } \\
\text { Zygophyceae }\end{array}$ & + & - & + & - & + & - & - \\
\hline Closterium acerosum Schrank & - & - & - & - & + & - & - \\
\hline $\begin{array}{l}\text { Closterium acutum Brébisson var. variabile } \\
\text { (Lemmermann) Krieger }\end{array}$ & + & + & - & - & - & - & - \\
\hline
\end{tabular}


- Microcystis forms blooms in eutrophic lakes, while Planktothrix also develops in waters with a more moderate degree of trophism and, in deep subalpine lakes, is considered as an indicator of mesotrophic condition (Reynolds 1998).

The Castreccioni reservoir could undergo Planktothrix agardhii blooms, passing in time from the oligomesotrophic situation to a mesotrophic one, and also Microcystis aeruginosa blooms, if the degree of trophism becomes even more accentuated. The presence of these two species, which could alternate in bloom formation according to the different environmental conditions and cycle of seasons, renders the lake's situation particularly delicate, and worthy of ongoing observation of its evolution. The problem posed by the Lake of Castreccioni appears similar, taking into consideration the due proportions, to that stated by Cook et al. (2004) for Greece, where the occurrence of hepatotoxic cyanobacterial blooms in many lakes and reservoirs, and the presence of Cyanobacteria also in oligotrophic surface water sources, bear grave consequences for the use of these hydric resources for domestic drinking supplies. In recent decades, cyanobacterial blooms have become more frequent throughout the world, and particularly, as far as the geographic area under study is concerned, in the Italian territory and in the Mediterranean basin. The general situation in Italy, where cyanobacterial blooms are frequent and due above all to Planktothrix (Oscillatoria) agardhiirubescens complex, is described in Funari (1999). In central Italy blooms of Planktothrix rubescens are reported for the Albano and Fiastrone water bodies (Viaggiu et al. 2003). But, in the immediate vicinity of the Fiastrone and Castreccioni reservoirs, there is another artificial lake of the same typology, the reservoir of Gerosa, which in the last years presented repeatedly, during the cold months, cyanobacterial blooms due to Planktothrix agardhii (authors' observations). In other Mediterranean regions, cyanobacterial blooms of various species of Microcystis are more common, and one can notice many case studies from Greece (Lanaras et al. 1989), Israel (Banker et al. 1997); Sukenik et al. 1997), Egypt (Brittain et al. 2000), Algeria (Menaa 2000), Morocco (Oudra et al. 2001), France (Vesie et al. 1997, Briand et al. 2002), Spain (Quesada et al. 2000), and Portugal (Vasconcelos 2001).

\section{Characterization of the trophic level}

With regard to total phosphorus, the OECD method takes into account the mean value of spring circulation, which in our case referred to the month of March and was $12 \mathrm{mg} \cdot \mathrm{m}^{-3}$. For chlorophyll, both the mean annual value of the euphotic zone and the maximum value were considered, which in our case were 2.3 and $5.9 \mathrm{mg} \cdot \mathrm{m}^{-3}$, respectively. Instead, for transparency, the method foresees the use of both the mean value and the minimum value recorded in the course of the year, which in our case were 3.2 and $2.2 \mathrm{~m}$, respectively. The resulting trophic level classification for the reservoir is reported in Table 3 using the fixed boundary system, and in Table 4 using the probability distribution for trophic categories.

On the basis of the former system, the reservoir waters under study can be classified as "oligotrophic" on account of their chlorophyll content referred both to the mean and maximum value, whereas they appear to be "mesotrophic" with respect to total phosphorus and transparency.

The rigid schemes imposed by the fixed boundary system do not appear to be in agreement, being exceeded by the probability distribution for trophic categories that, with respect to phosphorus and chlorophyll, leads the reservoir to be be classified as oligotrophic, with a little tendency to a mesotrophic condition. The transparency parameter, which yields a higher trophic level value, appears the least reliable one, because it is strongly conditioned by contingent conditions (turbidity, suspended materials due to abundant rains) not correlated with the algal biomass.

Table 3. Trophic classification of the reservoir based on fixed boundary system in the period June 2001 - June 2002.

\begin{tabular}{|c|c|c|c|}
\hline $\begin{array}{l}\text { Total } \\
\text { phosphorus: } \\
\text { Mean value }\end{array}$ & $12 \mathrm{mg} \cdot \mathrm{m}^{-3}$ & $\begin{array}{l}\text { Trophic } \\
\text { category }\end{array}$ & Mesotrophic \\
\hline $\begin{array}{l}\text { Chlorophyll a: } \\
\text { Mean value } \\
\text { Euphotic zone }\end{array}$ & $2.3 \mathrm{mg} \cdot \mathrm{m}^{-3}$ & $\begin{array}{l}\text { Trophic } \\
\text { category }\end{array}$ & Oligotrophic \\
\hline $\begin{array}{l}\text { Chlorophyll a: } \\
\text { Maximum value } \\
\text { Euphotic zone }\end{array}$ & $5.9 \mathrm{mg} \cdot \mathrm{m}^{-3}$ & $\begin{array}{l}\text { Trophic } \\
\text { category }\end{array}$ & Oligotrophic \\
\hline $\begin{array}{l}\text { Transparency: } \\
\text { Secchi disc } \\
\text { Mean value }\end{array}$ & $3.2 \mathrm{~m}$ & $\begin{array}{l}\text { Trophic } \\
\text { category }\end{array}$ & Mesotrophic \\
\hline $\begin{array}{l}\text { Transpa rency: } \\
\text { Secchi disc } \\
\text { Minimum value }\end{array}$ & $2.2 \mathrm{~m}$ & $\begin{array}{l}\text { Trophic } \\
\text { category }\end{array}$ & Mesotrophic \\
\hline
\end{tabular}


Table 4. Probability distribution for trophic categories of the reservoir in the period June 2001 - June 2002.

\begin{tabular}{|c|c|c|}
\hline $\begin{array}{l}\text { Total } \\
\text { phosphorus: } \\
\text { Mean value }\end{array}$ & $12 \mathrm{mg} \cdot \mathrm{m}^{-3}$ & $\begin{array}{l}\text { 5\% Ultra-oligotrophic } \\
59 \% \text { Oligotrophic } \\
\text { 36\% Mesotrophic }\end{array}$ \\
\hline $\begin{array}{l}\text { Chlorophyll a: } \\
\text { Mean value } \\
\text { Euphotic zone }\end{array}$ & $2.3 \mathrm{mg} \cdot \mathrm{m}^{-3}$ & $\begin{array}{l}\text { 4\% Ultra-oligotrophic } \\
56 \% \text { Oligotrophic } \\
\text { 38\% Mesotrophic } \\
\text { 2\% Eutrophic }\end{array}$ \\
\hline $\begin{array}{l}\text { Chlorophyll a: } \\
\text { Maximum value } \\
\text { Euphotic zone }\end{array}$ & $5.9 \mathrm{mg} \cdot \mathrm{m}^{-3}$ & $\begin{array}{l}\text { 0\% Ultraoligotrophic } \\
63 \% \text { Oligotrophic } \\
31 \% \text { Mesotrophic } \\
\text { 6\% Eutrophic }\end{array}$ \\
\hline $\begin{array}{l}\text { Transparency: } \\
\text { Secchi disc } \\
\text { Mean value }\end{array}$ & $3.2 \mathrm{~m}$ & $\begin{array}{l}\text { 4\% Oligotrophic } \\
\text { 46\% Mesotrophic } \\
\text { 44\% Eutrophic } \\
6 \% \text { Hypertrophic }\end{array}$ \\
\hline
\end{tabular}

The biological indications about the trophic status of the reservoir are given by the composition of the phytoplankton community, where there is a clear dominance of the species characteristic of the oligotrophic and oligo-mesotrophic levels. Among them: Ceratium hirundinella and fo. piburgense (Zederb.) Bachmann , Peridinium cinctum, Dinobryon divergens, D. sertularia and var. protuberans (Lemm.) Krieger, Asterionella formosa, Cyclotella ocellata, C. schumannii (Grun.) Hakansson, Fragilaria capucina Desmazières, F. ulna var. acus (Kütz.) Lange-Bert., Botryococcus braunii Kützing, Coelastrum reticulatum (Dangeard) Senn, Eudorina elegans, E. unicocca G.M. Smith, Oocystis gloeocystiformis Borge. The Cyanobacteria, which are commonly found in waters with a higher trophic level, were quantitatively very little represented in the lake. The most frequent taxon, but never abundant, was Chroococcus limneticus Lemm., which indicates an oligotrophic level or, at most, an oligo-mesotrophic one.

From the above information, the lake appears to be in good "health", even though the presence of some forms indicating eutrophication, such as Aphanocapsa delicatissima W. et G.S. West, A. incerta (Lemm.) Cronberg et Komárek and Spirulina gigantea Schmidle, cannot be neglected. In particular, Planktothrix agardhii and Microcystis aeruginosa, two potential toxic taxa susceptible to give blooms, provide reasons for some worry.

\section{Conclusion}

On the basis of our findings according to the chemical and biological parameters used, substantial agreement was found in the definition of the "trophic level" of the reservoir, which is in an oligo-mesotrophic state, but with a marked prevalence of the trophic level. The correlation between the former parameters (phosphates, chlorophyll, $\mathrm{BOD}_{5}$ ) and the photosynthetic planktonic community appears on the whole very significant. Instead, we consider the result obtained from the transparency parameter to be excessive, and this is undoubtedly due more to the turbidity of the suspended clays, rather than to the richness of the phytoplankton community.

For the moment, therefore, the lake appears to be in a good state, but the presence of some species that potentially produce toxins (Planktothrix agardhii and Microcystis aeruginosa) - even if they showed till now sporadic trichomes or colonies - should not be overlooked. Should there be a large-scale development of these Cyanobacteria in conditions of ecological unbalance, it would seriously compromise the tourism and recreational features of the lake (fishing, swimming) and, above all, the use of its water for drinking purposes.

The trophic condition of the Castreccioni artificial lake seems at the moment undoubtedly better than those of the S. Serrada and Azibo reservoirs, in Portugal, both classified as meso-eutrophic from winter to the beginning of summer, and as eutrophic from this period onwards (Geraldes \& Boavida 2003). However, while greater worry for the Portuguese reservoirs seems to focus on the fear of further eutrophication and water quality degradation, the central Italian lake already poses implications of toxicological type, because of the checked presence of some Cyanobacteria potentially producers of toxins, as detailed above. Hence, a constant monitoring of the reservoir is needed, in order to keep the life cycle of these harmful organisms under control and to check the chemical, physical and biological conditions responsible for possible blooms; that already happened in other reservoirs of the central Apennines without a certain understanding of the causes.

\section{References}

American Public Health Association, American Water Works Association \& Water Environment Federation 1998. - Standard Methods for the examination of water and wastewater. American $\mathrm{Pu}-$ blic Health Association, Washington, DC.

Anagnostidis K. \& Komárek J. 1988. - Modern approach to the classification system of cyanophytes. 3. Oscillatoriales. Arch. Hydrobiol. / Algol. Studies, 50-53, 327-472. 
Banker R., Carmeli S., Hadas O., Teltsch B., Porat R. \& Sukenik A. 1997. - Identification of cylindrospermopsin in Aphanizomenon ovalisporum (Cyanophyceae) isolated from Lake Kinneret, Israel. J. Phycol., 33, 613-616.

Briand J.F., Robillot C., Quiblier-Lloberas C. \& Bernard C. 2002. A perennial bloom of Planktothrix agardhii (Cyanobacteria) in a shallow eutrophic French lake: limnological and microcystin production studies. Arch. Hydrobiol., 153, 605-622.

Brittain S., Mohamed Z.A, Wang J., Lehmann V.K.B., Carmichael W.W. \& Rinehart K.L. 2000. - Isolation and characterization of microcystins from a River Nile strain of Oscillatoria tenuis Agardh ex Gomont. Toxicon, 38, 1759-1771.

Chapman D. 1992. - Water quality assessment. Chapman and Hall, Ltd, London, 585 p.

Chorus I. \& Bartram J. 1999. - Toxic Cyanobacteria in water. World Health Organisation, London and New York, 416 p.

Cocchioni M., Bernacchia G., Nacciarriti L., Grappasonni I. \& Pellegrini M.G. 1999. - Lake derived drinkable waters : results of a multidisciplinary study. Ig. Mod. 111, 433 - 463.

Compère P. 1986. - Flore pratique des algues d'eau douce de Belgique.1. Cyanophyceae. Jardin Bot. Nat. Belgique, Meise, 120 p.

Compère P. 1989. - Flore pratique des algues d'eau douce de Belgique. 2. Pyrrophytes, Raphidophytes, Euglenophytes. Jardin Bot. Nat. Belgique, Meise, 208 p.

Cook C.M., Vardaka E. \& Lanaras T. 2004. - Toxic Cyanobacteria in Greek Freshwaters, 1987-2000 : occurrence, toxicity, and impacts in the Mediterranean region. Acta hydrochim. hydrobiol., 32, 107124.

Cronberg G. \& Komárek J. 1994. - Planktic Cyanoprokaryotes found in South Swedish lakes during the XIIth International Symposium on Cyanophyte Research, 1992. Arch. Hydrobiol./ Algolog. Studies, 75, 323-352.

Dell'Uomo A. \& Masi M.A. 1988. - Studio floristico-ecologico delle Diatomee del Lago di Tovel (Nord-Italia). Riv. Idrobiol., 27, 317 - 348.

Desikachary T.V. 1959. - Cyanophyta. Indian Counc. Agr. Res., New Delhi, 686 p.

Ettl H. 1983. - Süßwasserflora von Mitteleuropa, 9. Chlorophyta I: Phytomonadina. G.Fischer, Jena, 807 p.

Ettl H. \& Gärtner G. 1988. - Süßwasserflora von Mitteleuropa, 10. Chlorophyta II: Tetrasporales, Chlorococcales, Gloeodendrales. G. Fischer, Stuttgart, New York, 436 p.

Falconer I.R. 1989. - Using activated carbon to remove toxicity from drinking containing cyanobacterial blooms. J. Am. Water Works Assoc., 81, 102-105.

Falconer I.R. 1993. - Measurement of toxins from blue-green algae in water and foodstuffs. Pages 165-175 in Algal Toxins in Seafood and Drinking Water. Falconer I.R. (ed.). Academic Press, London.

Falconer I.R. 2001. - Toxic cyanobacterial bloom problem in Australian waters : risks and impacts on human health. Phycologia, 40, 33-53.

Funari E. (ed.) 1999. - Aspetti sanitari della problematica dei cianobatteri nelle acque superficiali italiane. Istituto Superiore di Sanità, Roma, 151 p

Geitler L. 1932. - Cyanophyceae. Rabenhorst's Kryptogamenflora von Deutschland, Österreich und der Schweiz, 14, 1-1196.

Geraldes A.M. \& Boavida M.G. 2003. - Distinct age and landscape influence on two reservoirs under the same climate. Hydrobiologia, 504, 277-288.

Himberg K., Keijola A.M., Hiisvirta L., Pyysalo H. \& Sivonen K. 1989. - The effect of water treatment processes on the removal of hepatotoxins from Microcystis and Oscillatoria cyanobacteria : a laboratory study. Water Res., 23, 979-984.

Irsa-Cnr 1994. - Metodi analitici per le acque. Istituto Poligrafico e Zecca dello Stato, Roma, 342 p.
Jones G.J. \& Orr P.T. 1994. - Release and degradation of microcystins following algicide treatment of a Microcystis aeruginosa bloom in a recreational lake, as determined by HPLC and protein phosphatase inhibition assay. Water Res., 28, 871-876.

Komárek J. \& Anagnostidis K. 1999. - Süßwasserflora von Mitteleuropa, 19/1. Cyanoprokaryota: Chroococcales. G. Fischer, Jena, $548 \mathrm{p}$.

Krammer K. \& Lange-Bertalot H. 1991. - Süßwasserflora von Mitteleuropa, 2/3. Bacillariophyceae : Centrales, Fragilariaceae, Eunotiaceae. G. Fischer, Stuttgart, Jena, 576 p.

Lanaras T., Tsitsamis S., Chlichlia C. \& Cook C.M. 1989. - Toxic cyanobacteria in Greek freshwaters. J. appl. Phycol., 1, 67-73.

Menaa N. 2000. - A study about cyanobacteria in the reservoir of Lekhal (Algeria). Abstracts. Eurocyan Workshop : Europe Facing Toxic Cyanobacterial Blooms, Toulouse, France, December 1214.

Oudra B., Loudiki M., Sbiyyaa B., Martins R., Vasconcelos V. \& Namikoshi N. 2001. - Isolation, characterization and quantification of microcystins (heptapeptide hepatotoxins) in Microcystis aeruginosa dominated bloom of Lalla Takerkoust lake-reservoir (Marocco). Toxicon, 39, 1375-1381.

Philipose M.T. 1967. - Chlorococcales. Indian Counc. Agr. Res., New Delhi, 365 p.

Popovsky J. \& Pfiester L.A. 1990. - Süßwasserflora von Mitteleuropa, 6. Dinophyceae (Dinoflagellida). G. Fischer, Yena, Stuttgart, 272 p.

Prescott G.W. 1970. - Algae of the western Great Lakes area. Brown Company Publ., Dubuque, Iowa, 977 p.

Quesada A., Sanchis D., Carrasco D., Padilla C., Leganes F., Valiente E. \& del Campo F.F. 2000. - Cyanobacterial blooms in Spanish waterbodies. Abstracts. Eurocyan Workshop: Europe Facing Toxic Cyanobacterial Blooms, Toulouse, France, December 1214.

Reguera B., Blanco J., Fernández L. \& Wyatt T. (eds) 1998. - Harmful algae. VIII Internat. Conference on Harmful Algae. Grafisant, Santiago de Compostela, 635 p.

Reynolds C.S. 1984. - The ecology of freshwater phytoplankton. Cambridge Univ. Press, Cambridge, 384 p.

Reynolds C.S. 1994. - The long, the short and the stalled: on the attributes of phytoplankton selected by physical mixing in lakes and rivers. Hydrobiologia, 289, 9-22.

Reynolds C.S. 1998. - What factors influence the species composition of phytoplankton in lakes of different trophic status? Hydrobiologia, 369/370, 11-26.

Round F.E. 1981. - The ecology of algae. Cambridge Univ. Press, Cambridge, $653 \mathrm{p}$.

Ruzicka J. 1977. - Die Desmidiaceen Mitteleuropas, 1/1. E. Schweizerbart, Stuttgart, $292 \mathrm{p}$

Sabour B., Loudiki M., Oudra B., Oubraim S., Fawzi B., Fadlaoui S., Chlaida M. \& Vasconcelos V. 2002. - First results on Microcystis ichthyoblabe Kütz. toxic bloom in the hypertrophic Oued Mellah reservoir (Marocco). Ann. Limnol., 38, 13-22.

Sanchis D., Carrasco D., Padilla C., Leganés F., Fernández-Valiente E., del Campo F.F. \& Quesada A. 2002. - Spatial and temporal heterogeneity in succession of cyanobacterial blooms in a Spanish reservoir. Ann.Limnol., 38, 173-183.

Sládecek V. 1973. - System of water quality from the biological point of view. Arch. Hydrobiol., Ergebn. Limnol., 7, 1-218.

Starmach K. 1985. - Süßwasserflora von Mitteleuropa, 1. Chrysophyceae und Haptophyceae. G. Fischer, Stuttgart, New York, 515 p.

Sukenik A., Rosin C., Porat R., Teltsch B., Banker R. \& Carmeli S. 1998. - Toxins from cyanobacteria and their potential impact on water quality of Lake Kinneret, Israel. Israel J. Plant Sci., 46, 109-115. 
Vasconcelos V. 2001. - Freshwater cyanobacteria and their toxins in Portugal. Pages 62-67 in Cyanotoxins - Occurrence, Causes, Consequence. Chorus I. (ed.). Springer, Berlin.

Vezie C., Brient L., Sivonen K., Bertru G., Lefeuvre J.C. \& Salkinoja-Salonen M. 1997. - Occurrence of microcystin-containing cyanobacterial blooms in freshwater of Brittany (France). Arch. Hydrobiol., 139, 401-413.

Viaggiu E., Calvanella S., Mattioli P., Albertano P., Melchiorre S. \&
Bruno M. - 2003. Toxic blooms of Planktothrix rubescens (Cyanobacteria/Phormidiaceae) in three waterbodies in Italy. Pages 569-577 in Cyanobacteria/Cyanophyta. Morphology, Taxonomy, Ecology. Hernández-Mariné M., Komárek J. \& Lhotsky O. (eds). E. Schweizerbart, Stuttgart.

Vollenweider R.A. \& Kerekes, J.J. 1982. - Eutrophication of waters. Monitoring, Assessment and Control. Organisation for Economic Cooperation and Development, Paris, 154 p. 